\title{
Sappho as Aphrodite's Singer, Poet, and Hero(ine): The Reconstruction of the Context and Sense of the Kypris Song
}

\author{
Anton Bierl
}

In my contribution on the Brothers Song (chapter 14) I have already dealt with its relation to the second entirely newly discovered text, i.e. the Kypris Song. ${ }^{1}$ The new papyrus reproduces the structure of the Alexandrian edition of Sappho' poetry arranged according to the principle of meter and internally in the alphabetical order. Despite their direct vicinity, both songs, set in Sapphic stanzas, beginning with words featuring the letter $\Pi$, and assembled in the famous Book One of the Alexandrian scholarly edition, will hardly ever have been performed in sequence. However, it is theoretically possible that at some point in time they were sung together, especially if both songs were originally performed chorally at Messon. Particularly in later reperformances at the PanLesbian sanctuary, mythopoetic songs about the family could be alternated with song expressing the sufferings of love and the prayer to find relief through Aphrodite or other deities. Even later reperformances could have put both songs together for a monodic delivery by a female singer in the symposium as well, both songs assuming a new meaning. The Brothers Song will have been read now as a biographical statement and the Kypris Song as a lyric, almost romantic outcry about the abyss of passion and love experienced by an individual, normally understood as the single poetess Sappho embedded in the specific historical context of Mytilene, with family and personal friends.

A Hellenistic papyrus can even mirror a direct performance context and its new practice of putting together songs on the basis of thematic associations. The recent discovery of the Cologne papyrus P. Cologne XI.429 (3rd century BC) yielding three parts - a self-referential piece about poetry and afterlife, the Tithonus Poem (formerly fr. 58.12-22), and a non-genuine Hellenistic, pseudoSapphic piece on Orpheus and love-follows this principle. ${ }^{2}$ But, as said, in

1 See also Schlesier as well as Boehringer and Calame in this volume.

2 See Bierl (2008), (2010), and (2016). On the link between the Brothers Song and the Kypris Song as well as on the idea of an Alexandrian collection on a thematic basis, see now also Neri (2015) 71-73.

(C) ANTON BIERL, 2016 | DOI: 10.1163/9789004314832_017

This is an open access chapter distributed under the terms of the Creative Commons AttributionNoncommercial 3.0 Unported (CC-BY-NC 3.0) License. 
our P. Sapph. Obbink of the 3rd century AD this is rather unlikely, although the alternation between family and love songs in the first parts of Sappho's Book One might still have held a special meaning in the Hellenistic editor's eye, beyond the criterion of the same incipit.

\section{Structure, Texture, and Meaning of the Kypris Song}

In this paper I will provide a brief analysis of the structure, texture, and meaning of the Kypris Song. After an initial interpretation, I will present some recent reconstructions, discuss their problematic hermeneutical presuppositions, develop some hypotheses regarding the original as well secondary performance context, and finally elaborate upon some thoughts regarding the metapoetic relevance of this song.

First of all, I reproduce Obbink's (chapter 1) text with the main thematic units on the right side and my translation beneath:

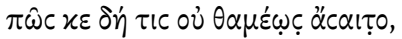

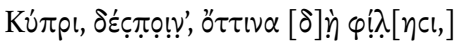

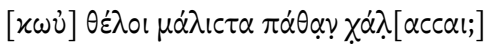

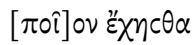

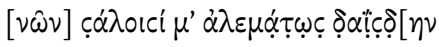

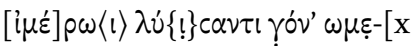

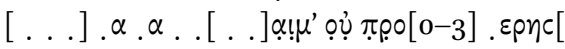

$[-\smile] v \xi ฺ \varepsilon p .[$.] $]$ !

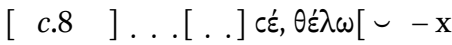

$[-\smile-\mathrm{x} \tau 0 \hat{v}] \tau 0 \pi \dot{\alpha} \theta \eta[\nu \cup-\mathrm{x}$

$[-\smile-\mathrm{x}-], \alpha \nu, \varepsilon^{\prime} \gamma \omega \delta^{\prime} \dot{\varepsilon}^{\prime} \mu^{\prime} \alpha v^{\prime} \tau \alpha \mathrm{l}$

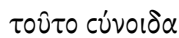

]. [.] . $.010[\ldots . .$.$] .$

] $\varepsilon v \alpha \mu[$

].[.].[
A: generalized, rhetorical question introduced with tis: how not be nauseated about the person (potential optative with $x \varepsilon)$,

address to Kypris/ whomever you love, how not desire for release from passion? B: question: what purpose?

5 physical violence and bodily experience: shakes desire, loss of body control

C: personal consequences: wish ...

to experience/suffering

but I: awareness

knowledge: cognitive conclusion:

consequence for myself

mankind (?) 
How could one not be hurt/nauseated over and over again, Mistress Kypris, by anybody, whomever one really loves, and not, above all, want release from the passions?

What do you have in mind, in pointlessly [brutally] tearing me apart with shakes through desire that loosens my knees? ...

... not ...

$\ldots$

you, I wish ...

to suffer this

but I am conscious of this

for my own self.

This song characterizes the quintessential situation of unrequited love in the typical three-step structure: universal insight (A) gives way to the lover's symptoms (B), which reaches a cognitive conclusion (C). In lines 1-3 of the first strophe we encounter a generalized statement in two parts with the indefinite pronoun $\tau \iota \varsigma$, almost formulating either a human law of love, comparable to Sappho's fragments $16.3^{b}-4$ and $58.25^{-26}$, or the basis of erotic anthropology: the 'discourse of love' is 'absence', ${ }^{3}$ which implies violent suffering. A generalized relative clause introduced by an accusative relative pronoun follows

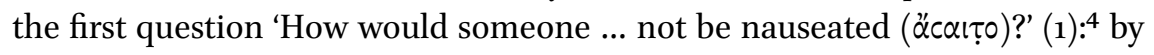

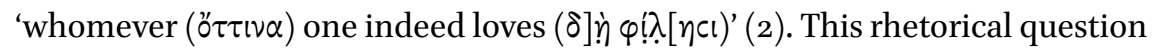
implies that nausea and pain are inevitable; everyone in such a situation suffers again and again. Before the relative clause the singing person addresses Kypris, the mistress ( $\delta \varepsilon \dot{c} c \pi$ ọ $\left.v^{\prime}, 2\right)$. The 'I' is most likely Sappho, though the first strophe does not contain a first person, singular or plural, rather the sentiment applies universally. Only in line 5 do we zoom in on the 'I/we' $[\mu \varepsilon]$ and in line 11 the

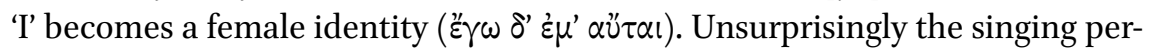
son does not summon Hera, goddess of marriage, authority, and seafaring, who presides over the famous Pan-Lesbian sanctuary of Messon, but Aphrodite, the goddess of love. The second part of the rhetorical question - a negated optative with $x \varepsilon v$ (negation with ov) insinuates a strong affirmation-continues with

3 See Barthes (1979) 13-17.

4 The diction $\alpha$ calțo in line 1 recalls the address to Aphrodite in Sappho fr. 1, esp. lines 3-4: $\mu \dot{\eta}$

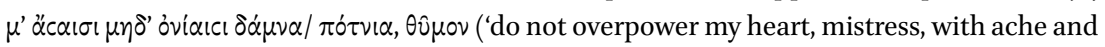
anguish', transl. Campbell). 
[ $\chi \omega \dot{0}] \theta \dot{\varepsilon} \lambda$ or expressing a strong wish in the ensuing infinitive:... 'and (how could one) not above all wish for release from the passions?' (3) Through the striking

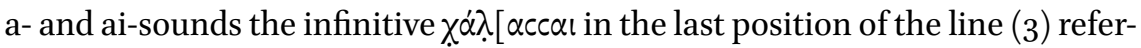
ences the emphatic $\ddot{\alpha} c \alpha i \tau o ~(1)$ as the last word of the first verse. The pain of love is counterbalanced by the wish for respite from it. ${ }^{5}$

The last line of the first strophe introduces a new thought, an address to a 'you' who must be identical with Kypris. In his preliminary version Obbink

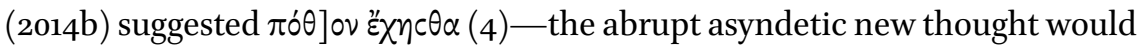
express the affliction of love: 'You possess desire/ you have sex-appeal'- $\pi \dot{\theta} \theta$ ]ov would then be resumed by i $i \dot{\varepsilon}$ ] $\rho \omega\langle\iota\rangle$ ('desire', 6). ${ }^{6}$ But in the editio princeps Obbink (2014b, 49), as in chapter 1, adopts Ewen Bowie's suggestion and inter-

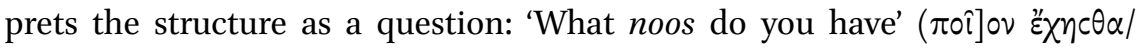
$\left.[\nu \omega \hat{v}], 4^{-5}\right)$ to hurt me, i.e. what is your rationale behind this? This question would be followed by a drastic expression of an explicative infinitive to unfold Aphrodite's brutal aggression against the physical integrity of the person bemoaning one's fate: 'What sort of thoughts do you have to tear me idly

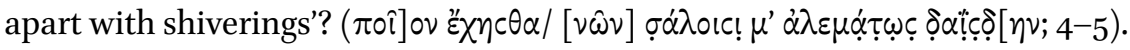

The structure is again simple and direct. Through the generalized rhetorical

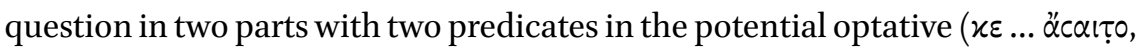

5 Schlesier, in this volume, interestingly reconstructs line 3 taking $x \omega \dot{\omega} c]$ from West (2014) and $x \dot{\alpha} \lambda[\varepsilon \varepsilon c \alpha$ l from Obbink's editio princeps (2014b) and changing the genitive plural $\pi \dot{\alpha} \theta \alpha \nu$ to the

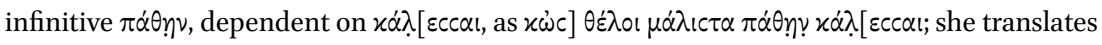
the line: 'even whenever one would most want to call for experiencing'. The nausea would stem from "the psychic impulse, the will ... to "call" to the "experience" (of love) the person who is loved. The person would be disgusted by his/her own irresistible will to summon the beloved to suffer love as well. The examples she provides for the construction of $x \alpha \lambda \varepsilon \dot{\varepsilon} \omega$ followed by an infinitive (e.g., according to LSJ s.v. I: Il. 10.197; Soph. El. 996; Phil. 466) are all concrete, the person calling in loud voice to do something (in the sense of $\pi \alpha p \alpha \kappa \alpha \lambda \varepsilon^{\prime} \omega$ ), e.g. to participate in council, help, or more abstract, the moment calling (since it is apt) to sail off. But here Sappho would use the verb to call forth a passive experience, the suffering in love. As I see it, this train of thought is somehow complicated and artificial. If Sappho wished the beloved person to reciprocate she would hardly have said 'please, I call you to suffer/experience'-not a real seduction, but a deterrent—rather in simple terms 'please, love me as well'. Therefore I believe that even in her general reflection Sappho would probably have used just the very

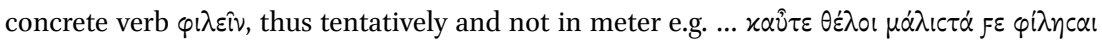

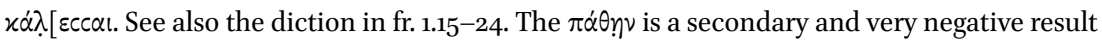
that a lover would hardly address. Therefore it seems unlikely that Sappho makes use of it in connection with $x \alpha \lambda \varepsilon \dot{\varepsilon} \omega$ despite her analytic self-awareness.

6 On other possible supplements, see Obbink in chapter 1 of the volume and Obbink (2014b) 47-48, e.g. xäpov ('and desire') (48). 
1 and $\theta \dot{\varepsilon} \lambda \circ$ ol, 3) Sappho, or the choral group, having addressed Kypris, laments the corollary of the state of love. She reproaches the goddess for her cruelty in hurting the speaker in such a brutal way. The bodily affliction is extremely strong: the speaking 'I' is like a wounded warrior, transfixed and pierced, her flesh torn apart. She can only pray for relief. Again and again Sappho compares the quintessentially male experience of the warrior wounded in battle with the girls' experience of erotic affliction. ${ }^{7}$ In order to testify to the drastic implications Sappho as chorus leader sings about it as her own suffering, while the group can reenact it. By doing so, the girls have their encounter with beauty on the level of mind and body. Through mimesis they reenact Sappho's passion and thus assume the choral leader's affliction. Full of love, they can themselves become objects of love. In the same way as young men are initiated into male society through war and near-death-experiences, so are they introduced into female values and society by becoming beautiful maidens that men adore and wish to marry.

\section{Monodic Reconstructions of the Beginning: Aphrodite's Refusal to Love Sappho?}

Very different, but less likely, are West's and Ferrari's similar restorations of the first two strophes, both recently contending that Aphrodite refuses to love. ${ }^{8}$ In this scenario we clearly have a solo performance of a real, individual Sappho as a poetic and biographic voice.

I provide the text and translation of the late Martin West:

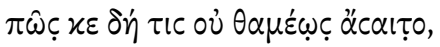

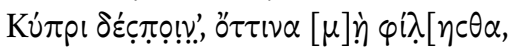

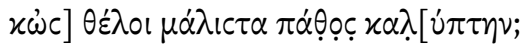

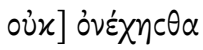

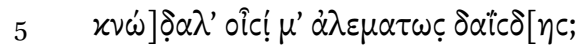

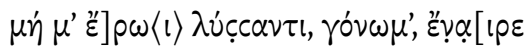

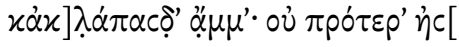

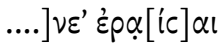

7 See Rissman (1983).

8 West (2014) 9-12, esp. 12 and Ferrari (2014) 13-15. 
How can a woman help being regularly heartsick, my Lady, if you do not love her, and when she would most wish to conceal her passion, you do not hold back

the mordacious pests with which you ravage me to no purpose?

Do not, I beseech you, despoil me with raging love and devastate us. You were not previously ... to me when I was in love.

The general law of love seems to morph into a personal and direct attack on Kypris because she does not requite the love of the woman who, being identical with the lyric 'I', seeks to hide her passion, a rather unusual concept since nowhere else do we find Aphrodite in a direct love relationship with Sappho or women of her circle, rather the goddess allows love to blossom between Sappho and other girls. ${ }^{9}$ But normally Kypris is responsible for the typically lyric situation of unrequited love; the distance of the absent beloved generates the feeling of desire, and the first person speaker bemoans this constellation that creates excruciating suffering. It is in this sense that West and Ferrari wish to understand $\varphi \iota \lambda \varepsilon i v$ in line 2: 'a deity's favor towards an individual, inferred from his or her fortunes'.10 West and Ferrari seem to say that the woman, i.e. Sappho, suffers from unrequited love (of course not towards the deity but towards another woman of her circle) and lays the blame at Aphrodite's feet, since she gives Sappho's passion 'full rein', even though Sappho tries to conceal it. ${ }^{11}$ Despite the well attested sense of philia as a general relation of mutual favor between deity and a mortal, the risk in understanding the phrase in a more concrete sense as 'to love', e.g. as in fragment $16.3 \mathrm{~b}-4$, is high, since the passions Sappho speaks about stem from love. Moreover, the lyric 'I' typically does not conceal her passion, but rather tends to act it out in a decisive speech-act as compensation. ${ }^{2}$

Ferrari understands the poem in a similar way but restores it differently, especially in lines $5^{-8::^{13}}$

\footnotetext{
$9 \quad$ See also Schlesier in this volume.

10 West (2014) 10.

11 West (2014) 10 and Ferrari (2014) 13-14.

12 See Calame (1999b) $5^{2-56}$ and also Schlesier in this volume.

13 Ferrari (2014) 13-15.
} 


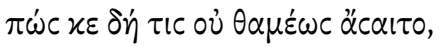

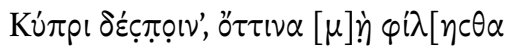

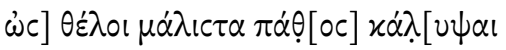
$\left.\mu \eta \delta^{\prime}\right]$ o $v \varepsilon \varepsilon^{\prime} \chi \eta c \theta \alpha$

$5 \quad$ còv] ḉád

$\left.i \mu \varepsilon^{\prime}\right] \rho \omega\langle\iota\rangle \lambda \dot{v}\{!\} c \alpha \nu \tau \iota \gamma{ }^{\prime} v^{\prime}, \grave{\omega}\langle\iota\rangle \mu^{\prime}, \varepsilon^{\prime} \gamma\left[\omega\left[\delta \varepsilon^{\prime}\right.\right.$

$\left.\lambda \alpha^{\prime}\right] \lambda \alpha \pi \alpha c[\varphi] \alpha i \mu^{\prime}$ o ${ }^{\prime} \pi \rho \circ[\tau o ́ v o l c] \pi \varepsilon p \eta^{\prime}[\eta \nu$

8

...] $v \varepsilon \varepsilon \varepsilon p .[.] \alpha \iota$

And he provides the following Italian translation:

Come non si cruccerebbe più volte, Kypris padrona, chiunque tu non favorisci quando in sommo grado vuol celare la sua passione né lo trattieni?

Fra sussulti ondosi tu vai straziandomi con il desiderio che, ohimé, già mi piegò le ginocchia, ma io credo che le raffiche non sopravanzeranno gli stralli

Ferrari clearly thinks that any person whom Aphrodite does not care for (see Hesiod, Theogony 96-97), suffers when (s)he wishes to hide her/his passion. Then he seems to continue the generalized relative clause: 'and whomever you do not hold back'. Aphrodite does not reciprocate the love and, while the person tries to conceal her/his passion, Aphrodite does not stop or even moderate this person's feeling. Again we would have the paradox of love: you suffer and it is inevitable - a general experience.

The next stanza then, for Ferrari, is dedicated to the terrible actions of Kypris. With moving spasms, she afflicts the 'I' with desire that bends the knees. According to him the 'I' thinks - a link to the metaphor of ships and storms of the Brothers Song preceding in the papyrus - that the boat will be in terrible danger of sinking.

Most recently Benelli (2015), heavily dependent on West's and Ferrari's reconstructions, restores the first lines as following:

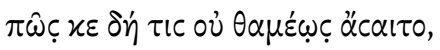

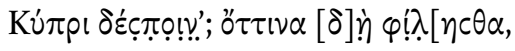




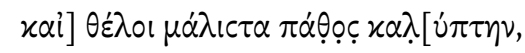

$$
\begin{aligned}
& \text { oủx] òvé } \chi \eta \in \theta \alpha \text {. }
\end{aligned}
$$

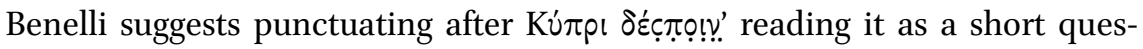
tion: 'How can someone not be hurt again and again, Queen Aphrodite?'-or: 'How can one help being regularly heartsick, Lady Kypris?' (1-2a). The rest of the first strophe (2b-4) he takes as the underlying reason for the preceding rhetorical question. Therefore he wants to link the proleptic relative clause

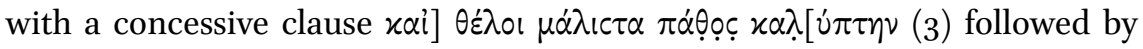
the apodosis in the indicative as 'a statement of an undoubted truth'. I provide a tentative translation: 'Whomever you really love, even though/if one most wishes to conceal one's passion, you do not restrain/hold back (him/her).' Since Benelli-he provides neither a translation nor an explicit explanation in his short contribution, but does so in the last part of a drafted article that he kindly sent me in advance of publication ${ }^{14}$ - assumes that the 'you' is Aphrodite, similar objections apply to his solution as well. Why should Aphrodite love someone, if it is not in the restricted sense of caring for the person, and why should she not tolerate it when the beloved hides his/her passions? The idea of suppressing one's passion has an almost Puritan flavor. Thus according to Benelli and in line with West, the sentence would imply that whoever is in the realm of love has to suffer. Even if the person in question-in Sappho's circle a girl - wishes to hide her feelings, Aphrodite, the goddess of love, does what she has to do and works just in the opposite direction, not holding her back but letting the passion loose. The ensuing sentence $x v \omega]$ ]̣́ $\dot{\lambda}$ oı $\mu^{\prime} \alpha \lambda \varepsilon \mu \alpha \dot{\alpha} \tau \omega c$ cọatị late Martin West, definitely refers to Aphrodite as well affecting the 'I' $(\mu$ ', 5$)$ directly, i.e. Sappho herself: 'With mordacious pests you ravage me to no purpose/ and with desire, which weakened the knees, o (greatest?) ...' (5-6). It would thus mean a desperate outcry against Aphrodite, the principle of love, the terrible force of passion that almost kills, ravaging the body, since one simply cannot restrain it. To fight against gods even the ones loving you is a vain hubris; therefore it is best to endure the excruciating effects that come with Aphrodite.

14 Benelli (in preparation), unpublished paper, last part. 
Be that as it may, we again witness how different presuppositions influence the reconstruction of a fragment as well as the hermeneutical framework in reading Sappho. Everything depends on our concept of eros and our understanding of the genre, the pragmatic context, and its function.

\section{Back to Obbink's Reconstruction and the Remaining Lines: Choral Performance}

Returning to the poetic description of violent passion in Obbink's restoration, we see that the cultural metaphor again stands, at least to some extent, in selfreferential relation to the performative execution, i.e. the choreia, the actual body movements of dancing. The destructive desire loosens the knees of the lyric 'I'; she can hardly stand, much less dance. This recalls the expression in the Cologne Sappho, P. Cologne XI.429 col. I.1-2 = Tithonus Poem, lines 5-6:

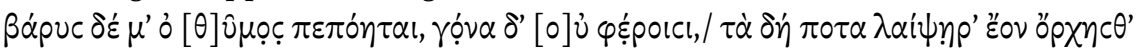
ic $\alpha \varepsilon \beta$ pioıc ('Heavy has my heart become, my knees bear it no more,/ which once were nimble enough to dance like deer'). ${ }^{15}$ Love is a terrible and destructive energy afflicting her entire body, over which she loses control. The typical attribute for love and its personification Eros is $\lambda \nu \sigma \mu \mu \varepsilon \lambda \dot{n} s$ (Hesiod, Theogony 911; see Sappho fr. 130.1 "Epoc.... $\lambda v \sigma \mu \varepsilon \dot{\lambda} \eta \eta c)$, 'loosening the limbs', like sleep (Homer, Odyssey 20.57, 23.343) and death (Euripides, Suppliant Women 47). It applies also to the warriors killed in action. Aphrodite has affinities with Ares and war, her statues sometimes armed, and her oriental predecessors were even warrior goddesses. ${ }^{16}$ Moreover, Sappho's use of war metaphors for love is a very common theme in her poetry. ${ }^{17}$ The brutal sparagmos, the tearing apart

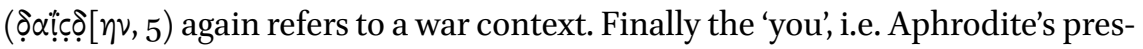
ence with respect to the beloved person, seems responsible for this wild reaction of love resulting in extreme agony and pathos (see $\pi \dot{\alpha} \theta \alpha \underline{v}, 3$ and $\pi \dot{\alpha} \theta \eta \nu, 10$ ). The Kypris Song thus represents a universal and human law, an anthropological and almost philosophical standpoint. Everybody has experienced this feeling

15 On the Cologne Sappho and chorality, see Bierl (2008) and (2016) esp. 310-311, 314, 318-319, 323-326.

16 Polycharmus of Naucratis ( $F G r H 640$ F 1) mentions that a nine-inch statue, probably armed, was brought around 688/85 BC from Paphos on Cyprus to Naucratis, the city where Charaxos traded wine and met Doricha; Paus. 3.23.1 mentions an armed image of Aphrodite in Cythera and Corinth (2.5.1); see Breitenberger (2007) 25-26 (with further sources).

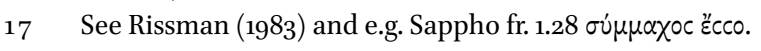


of love. Aphrodite and/or the beloved yet absent person make the singer suffer, and the pathological situation is conveyed through images of bodily destruction.

Thanks to overlaps with another papyrus (P. Oxy. 1231 fr. 16), formerly edited as fragment $26 \mathrm{v}$., Obbink could reconstruct the rest of the song..$^{18}$ Sappho, or the singing and fictional ' $\mathrm{I}$ ', experiences this extreme suffering, and expresses it in poetic song and dance. Sappho's almost philosophical, scientific, and selfdetached awareness regarding these symptoms of manic possession recalls Sappho's famous fragment $31.5^{-16}$ and indubitably forms the basis and prerequisite for her poetic production. As a female singer and fictional persona Sappho both bemoans and describes this pathological state, the contents of the actual song, which she-or she as choral leader together with her chorusbrings forth in mimesis over and over again, whenever she performs this poem. The perspective shifts from the impersonal, generalized $\tau$ เ (1) to a 'you' (2, 4; and $c \dot{\varepsilon}, 9)$ (Aphrodite or the beloved) and finally to the 'I' as conscious female person and poetess ( $\varepsilon^{\prime} \gamma \omega, 11$, and $12 ; \mu$ ', 5 ): 'I know of it myself'-in the sense: 'I have experienced it myself and I am conscious of the pathology' (11-12). In lines 9-10 at least two words are missing between 'I wish' and 'to suffer this', and Sappho, also on the basis of the newly restored line 2, must have said: 'I wish [no longer] to suffer this'. In her overwhelming passion she wishes for respite from her suffering. Also in fragment 1.3 Sappho prays to Aphrodite

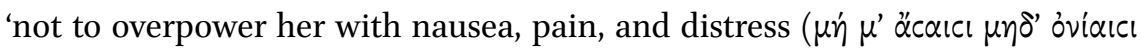
$\delta \dot{\alpha} \mu \nu \alpha$ - $\ddot{c} c \alpha ı c ı$ reminds of $\ddot{c} c \alpha i \tau o$ in line 1 of our Kypris Song). Thus the unrequited love of the 'you' generates passions she would rather forego or at least, find relief from, than live through. Therefore in fragment 1.25-26 Sappho also prays to Aphrodite to 'come' to her 'now again and to deliver' her 'from oppressive anxieties' (transl. Campbell).

\section{Some Thoughts Regarding Its Link to the Brothers Song, Original Setting, and Secondary Reperformance in the Symposium}

The Kypris Song follows the Brothers Song in the new papyrus, reflecting the alphabetical order of the Alexandrian edition of the first book, though not necessarily the performance context. Both poems, as many other initial fragments in the first book, seem to function on the principle of alternation and variation-family vs. love. But as I have argued in chapter 14, the Brothers 
Song follows a latently erotic and almost mystic agenda, having much to do with love as well. Whereas the Brothers Song only deals with love indirectly, the new song to Kypris addresses the goddess of love directly and offers a radical treatment of its consequences. The last two lines of the Brothers Poem express some hope of finding relief (lysis- $\lambda \dot{v} \theta \varepsilon \mu \varepsilon \varepsilon v, 24)$ from the turbulence of love affecting the family and the larger aristocratic order. Performance in sequence and reading in the Alexandrian edition, however, would have created a sharp contrast, rendering relief impossible. ${ }^{19}$ The 'I' is deeply wounded like a warrior, torn to pieces like a sacrificial victim. Sappho somehow stylizes herself as an epic hero attaining immortality through heroic death, ${ }^{20}$ which entails 'eternal, unwithering fame' ( $\left.x \lambda \dot{\varepsilon} \circ \varsigma \alpha \ddot{\varphi} \varphi \theta_{\iota} \tau \circ v\right)$. Sappho's suffering comes close to

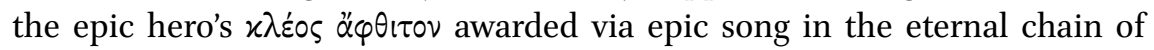
future reperformances. Also she claims eternal fame through her song. ${ }^{21}$ In the same way as the audience of the Iliad is visually confronted with detailed descriptions of heroes' bodies brutally mistreated, lacerated, and slashedaccording to Greg Nagy a compensation for the necessary and usual sacrifice in normal hero cult, ${ }^{22}$ so Sappho's audience envisages her body pierced and transfixed, and associates her with a heroic existence in an antagonistic relation to Aphrodite. ${ }^{23}$ Aphrodite somehow becomes a reflection of a heroic Sappho. The images of the hero and Sappho merge through the performance of kleos and love, the medium and essence of Sapphic song. ${ }^{24}$

The personal appeal is shaped as a rhetorical question universally applicable to the anthropology of love. The singing 'I' then addresses the goddess directly, making her responsible for the brutal symptoms that lead to total destruction and dissolution (lysis- $\lambda \dot{v}\{!\} \subset \alpha \nu \tau ! !, 6)$. The consequence for the 'I' is surprising: not merely rebellion but the clear wish for respite from the pathos, for less suffering, even though she must endure the utmost violence. The last movement highlights a personal consciousness and rational analysis of these symptoms. In contrast to the Brothers Song, which is based on a bio-mythic story with a dissenting address to an internal 'you' and the associative flow leading to a possible

19 On the performance of the Cologne Sappho in sequence based on a thematic principle, see Bierl (2008) and (2016).

20 On the feeling and wish of death due to the overwhelming passion and suffering caused by love, see Sappho frs. 31.15-16, 94.1, 95.11-12.

21 See especially the new part A1 of P. Cologne XI.429, col. I, 1-8 (new 1-11) before the beginning of the Tithonus Poem (formerly fr. 58.12-22). See Bierl (2010) 4.2 and (2016) 314-316.

22 See Nagy (2013a) 11-12.

23 See Nagy (1999/1979) 118-141 (on the hero Pyrrhos and Apollo) and (2013a) 333-334.

24 See Nagy (2013a) 55-69. 
but unlikely solution, here we have a more general address to a wider audience with a clear-cut and rational argumentation in three steps: 1) general statement as rhetorical question: love hurts; 2) personal address to the responsible divine agents: 'Kypris, why are you doing this, wounding me so?'; 3) personal consequence: the wish to have respite from suffering, based on a rational reflection of the physical symptoms.

Instead of the mimesis of personal dissent leading to the exposition of alternative measures in a flow of thoughts, we have an appeal to an implied audience, probably the Sapphic circle, to follow their leader's example. The poetics is simple. The song incorporates elements of 1 ) argumentative speech; 2) prayer and protest; 3) ritual lament; 4) observation of bodily symptoms, partly based on the Homeric idiom used to express the various ways a warrior is killed in action; 5) proto-philosophical and analytical thought.

The maidens of the chorus can reenact Sappho's poetic "outcry" when in love, when desire causes her pain, reaffirming her wish to retain relief following her sharp analysis facilitated by clear self-awareness. Again performing the singing 'I' becomes the speech-act of being in love and suffering. To some degree, the song is equivalent to being in love, and its performer, compensating for her loss, also woos the constantly absconding erotic object. ${ }^{25}$ The Kypris Song might also find its Sitz im Leben in some festival of Aphrodite or at Messon, the link to Dionysus being greater, since manic excitement and the ensuing sparagmos are strongly emphasized. Later reperformances will have brought the song to the symposium, changing its performance mode and its meaning. The originally choral song becomes monodic and a reflection about love and its corollaries in an educational context assumes the violent outcry of a biographic voice, of the personal Sappho in love.

\section{Conclusion}

All in all, the Kypris Song represents the quintessential poetics of love. Through its self-reflective and religiously charged message it reflects Sappho's anthropological, ritual, and proto-philosophical pronouncement of her leading principle which guides her entire performance production. Like a maxim or motto it stands between general law and very personal affection, between passion and rationality, and between overwhelming affliction from external forces and the inner strife to keep control over the extreme physical symptoms through

25 See Calame (1999b) $5^{2-56 .}$ 
self-awareness and pure mind. ${ }^{26}$ Joined in a direct appeal to the dominating mistress Aphrodite, the song tries to find a personal but communalized answer to the rationale behind the basic principle of love. As a 'discourse of absence' (Barthes [1979]), it asserts that whenever a person, be it Sappho, as a woman, or a girl from her circle in particular or anyone else in general, falls in love with someone, another girl from the circle perhaps, said person will be subjected to this principle. The unreachability of the object of desire causes severe pain acted out upon the body. The message inscribes itself in the texture of the performance and linguistic utterance. Love hurts, and only the wish to suffer less physically remains. The choral performers convey pain and passion, bemoaning that their tormented bodies can hardly dance; their knees weakening, they risk falling and they dissolve in a twisted motion of excruciating pain. But Sappho goes beyond that-her rebellion against the dominating force insists on asking Aphrodite directly about her intentions and rationale $(\nu \hat{\omega} \nu, 5)$ in tormenting her as alter ego and cultic adorant. The paradoxical logic behind this antagonism can only serve to regain strength and vitality, to become, so to speak, Aphrodite's hero(ine) and to express the personal wish to rage against imminent death. Sappho, and her female chorus, as self-aware ' $\mathrm{I}$ - this time she will probably not receive a direct answer from Kypris as she did in fragment 1.18-24-can compensate for the eternal pain and loss only by singing about it. The overwhelming, almost manic passion and the desire for respite bring forth poetic song and Sappho's survival through fame fostered by a chain of reperformances. Kypris thus functions, to some extent, like the poet's Muse. However, Aphrodite does not really inspire her according to the traditional epic concept, conveying her words through the performers' voice, rather the 'I', with her personal and rational analysis and her individual wish to understand the paradox of love and bemoan its effects, i.e. Sappho herself, acts out the song as compensation. Thus she is inspired by Aphrodite in a new sense: love makes Sappho produce song. As choral leader she can even make her entire choral group perform her words, and by performing these stanzas the girls, as plural 'I', discover the mechanism of love within themselves. In reenacting Sappho's pain and near-death-experience, the girls become imbued with love and consequently more attractive and marriageable to aristocratic men. After all, Sappho becomes Aphrodite's singer as compensation for the pain Sappho produces in

26 In this respect it might be comparable to the famous four lines of fr. $58.23-26$, missing in the Cologne Sappho, transmitted by P. Oxy. 1787, fr. 1.22-25 and fr. 2.1, the last two lines cited by Clearchus (in Athenaeus 15.687b). See Bierl (2008) ch. 5, (2010) 6.4, and (2016) 326-330 with the reference to fr. $16.3-4$. 
song and, just as Aphrodite's stylized antagonist hero(ine) attains $x \lambda \varepsilon \dot{\varepsilon} \circ \varsigma \ddot{\alpha} \varphi \theta$ iाov ('unwithering fame') after death, finds an afterlife as a woman poet whose fame resounds even today. 